\title{
Teoza (pobožavanje) kao novozavjetna i evanđeoska doktrina
}

Goran Medved

Beatus, Zagreb

goranmedved@bizg.hr

UDK: 27-1:27-23:277

Izvorni znanstveni članak https://doi.org/10.32862/k1.13.2.1

\section{Sažetak}

Ovo je drugi od dva članka ovoga autora, koji istražuju doktrinu pobožavanja, ponekad također zvanu teoza, deifikacija ili divinizacija. Prvi je članak predstavio pobožavanje kao biblijsku i povijesnu doktrinu. Ovaj članak predstavlja pobožavanje kao novozavjetnu i evanđeosku doktrinu. Prvi dio ovog članka obrađuje pobožavanje u novozavjetnoj teologiji. Drugi dio ovog članka daje prijedlog za oblikovanje evanđeoske doktrine o pobožavanju. Zbog svoje novozavjetnosti, pobožavanje bi trebalo zauzeti puno istaknutije mjesto u evanđeoskoj teologiji.

Ključne riječi: pobožavanje, teoza, deifikacija, divinizacija, imago dei, slika, sličnost, obnova, kristoza, utjelovljenje, kenoza, identitet, novo rođenje, sjedinjenje, posinjenje, proslavljenje, božanski život

\section{Pobožavanje u novozavjetnoj teologiji}

U ovom ću dijelu predstaviti Kristovo utjelovljenje kao temelj i nadu za pobožavanje. Pokazat ću kako pobožavanje izgleda u Pavlovoj teologiji dok piše o obnovi Božje slike u nama, o našem zajedničkom identitetu s Kristom, našem sjedinjenju s Kristom, našem posinjenju i eshatološkom ispunjenju. Raspravljat ću o pobožavanju u Petrovoj teologiji dok piše o našem novom rođenju i sudjelovanju u Božjoj naravi. Raspravljat ću o pobožavanju u Ivanovoj teologiji dok piše o novom rođenju i sudjelovanju u božanskom vječnom životu. Naposljetku, pokazat ću na koji su način djelo Isusa Krista i Duha Svetoga oboje ključni za pobožavanje. 


\section{Kristovo utjelovljenje i pobožavanje}

Kristov postanak čovjekom pruža temelj i nadu za pobožavanje. Utjelovljenje je „doktrina da je druga vječna Osoba Trojstva postala ljudskim bićem i 'preuzela tijelo' u Isusu iz Nazareta. Isus Krist bio je 'Riječ koja je postala tijelom' (Iv 1,14). Doktrina utvrđuje da je Isus bio jedna božanska osoba s božanskom i ljudskom naravi“ (McKim 1996, 140). Pitanje kako dvije naravi postoje zajedno u jednoj osobi ključno je za povijesnu kristologiju i važno za našu raspravu o pobožavanju.

Kao što je pokazano u prethodnom članku, svi rani crkveni Oci i drugi istaknuti teolozi, koji su pisali o teozi, naglašavali su važnost Kristova utjelovljenja za pobožavanje. Taj naglasak potječe od poznate i često ponavljane izjave o razmjeni: Krist je postao čovjekom, da bi ljudi mogli postati božanskima. Kroz utjelovljenje, božansko je biće odjenulo čovještvo da bi ljudska bića mogla odjenuti božanstvo. Stoga, Ivan izjavljuje: „I Riječ tijelom postade i nastani se među nama i vidjesmo slavu njegovu - slavu koju ima kao Jedinorođenac od Oca - pun milosti i istine... Doista, od punine njegove svi mi primismo, i to milost na milost“ (Iv 1,14.16).

U novozavjetnoj teologiji Kristova kenoza vodi do kršćanske teoze. Kenoza je „teološki termin za 'samoispražnjenje' Isusa Krista, pri čemu je uzeo obličje roba ili sluge (grč. doulos; lat. forma servi) da bi ostvario djelo spasenja kroz svoju smrt i uskrsnuće“ (McKim 1996, 153). Isus Krist „trajni lik Božji, nije se kao plijena držao svoje jednakosti s Bogom, nego sam sebe 'oplijeni' [ekenōsen, od glagola kenoō] uzevši lik sluge, postavši ljudima sličan; obličjem čovjeku nalik, ponizi sam sebe, poslušan do smrti, smrti na križu" (Fil 2,6-8). Učinak njegove smrti na križu, za one koji vjeruju, oblačenje je u Krista, ispunjenje Duhom Svetim i iskustvo sve Božje punine. Stoga, sjedinjene božanskoga s ljudskim ne nalazi se samo u Kristu nego i u kršćanima, kao posljedica djelovanja Svetog Trojstva.

\section{Pobožavanje u Pavlovoj teologiji}

\section{1) Obnova Božje slike u ljudima}

U prvom sam članku raspravljao o važnosti Imago Dei nauke za pobožavanje. Tri su točke posebno važne za daljnju raspravu: (1) stvaranje čovječanstva na Božju sliku, (2) pokvarenost te slike u čovječanstvu zbog pada i (3) obnova Božje slike u čovječanstvu. Kod Pavla, druga i treća tema naročito su razvijene. Čovječanstvo je pokvareno grijehom, ali djelo Isusa Krista (koji je Božja slika) može obnoviti čovječanstvo na Božju sliku.

U Rimljanima 1, Pavao opisuje silaznu putanju pada čovječanstva ,jer, iako su upoznali Boga, ne iskazaše mu slave ni zahvalnosti kao Bogu“ $(1,21)$ i „zamijeniše 
slavu besmrtnoga Boga kipovima, to jest prilikom smrtnog čovjeka, ptica, četveronožaca i gmazova" $(1,23)$. Oni, koji su bili stvoreni na Božju sliku, počeli su štovati slike ljudi i životinja. Odbacili su sliku Stvoritelja za slike stvorenja. Pavao opisuje dubinu pokvarenosti u ljudima, da su „puni svakojake nepravednosti“ $(1,29)$.

U Rimljanima 5,12-21, Pavao opisuje pad čovječanstva u Adamu te čovječju obnovu u Kristu. Izjavljuje da su grijeh (pokvarenost) i smrt (smrtnost) došli u svijet kroz Adama. Tada je čovječanstvo izgubilo ključna svojstva Božje slike svetost i besmrtnost. On dalje objašnjava preokret tog strašnoga gubitka kroz Isusa Krista. Prikazuje kontrast jednog čovjeka, Adama, koji je donio smrt čovječanstvu i drugog čovjeka, Isusa, koji je donio život, čak vječni život, čovječanstvu. Dalje u ovom članku, u opisu pobožavanja kod Ivana, ustvrdit ću da je taj vječni život zapravo božanski život s božanskim svojstvima, koji djeluje u kršćanima.

Prema Pavlu, Isus Krist je prava slika Boga. Dok je pisao Kološanima, na početku dugačkog odlomka koji otkriva identitet i djelo Isusa Krista, započinje: „On je slika i prilika Boga nevidljivoga..." (Kol 1,15). U Drugoj Korinćanima, Pavao piše o propovijedanju evanđelja i zašto su neki nesposobni vidjeti „slavu Krista koji je slika Božja“ (2 Kor 4,4). Zanimljivo je primijetiti da se ista riječ eikōn koristi u Postanku 1,26 u Septuaginti i u ova dva teksta na izvornom grčkom.

U Pavlovim spisima nalazimo temu obnove Božje slike u ljudima kroz Isusa Krista. U Rimljanima 8,28-30, Pavao piše o velikoj svrsi ${ }^{1}$ koju Bog ima za svoj narod:

Znamo pak da Bog u svemu na dobro surađuje s onima koji ga ljube, s onima koji su odlukom njegovom pozvani. Jer, koje predvidje, te i predodredi da budu suobličeni slici Sina njegova te da on bude prvorođenac među mnogom braćom. Koje pak predodredi, te i pozva; koje pozva, te i opravda; koje opravda, te i proslavi.

Dobro za koje Bog radi je da njegovi ljudi budu suobličeni slici Isusa Krista, da obnovi pravednost i slavu u njima. Grčka riječ za „suobličeni“ je summorphos, a definirana je kao "suobličen, dijeljenjem iste unutarnje biti-identiteta (forme); pokazivanje sličnog ponašanja koje proizlazi iz iste temeljne naravi.” ${ }^{2}$ Ovo su snažni argumenti za određenu vrstu kristoze ${ }^{3}$ jer je Krist Božja slika.

Tekst dalje ustvrđuje da oni koji su suobličeni Kristovoj slici, također su proslavljeni. Ovo podsjeća na ideju da je Adam bio u Božjoj slavi prije pada (prekriven, okružen ili obučen u slavu), a to je koncept koji drže neki drevni židovski i

1 Grčka riječ telos često se koristi u teološkim raspravama u smislu konačnog cilja ili svrhe.

2 HELPS Word-studies, 2011, „sýmmorphos”, Helps Ministries, pristupljeno 14. rujna 2017. , http://biblehub.com/greek/4832.htm.

3 „Kristoza“ je termin koji koristi Ben C. Blackwell u svojim djelima o Pavlu i teozi. Na primjer, vidi Blackwell, 2016, Christosis: Engaging Paul's Soteriology with His Patristic Interpreters. 
suvremeni kršćanski tumači (Enns 2010; Litwa 2012, 101-102). Isus Krist je sam pun Božje slave. „On, koji je odsjaj Slave i otisak Bića njegova“ (Heb 1,3). Ovdje vidimo kako su „slava“ $i$ „otisak“ (riječ srodna „slici“) povezani u ovom retku. Kroz Isusa Krista Bog vraća svoj narod natrag u svoju slavu, onu slavu koju je Adam imao prije pada. Slava je Božje svojstvo, stoga, kada su ljudi privedeni u njegovu slavu, riječ je o pobožavanju.

Još jedna Pavlova izjava u vezi kršćanskog preobraženja na Kristovu sliku kaže: „A svi mi, koji otkrivenim licem odrazujemo slavu Gospodnju, po Duhu se Gospodnjem preobražavamo u istu sliku - iz slave u slavu" (2 Kor 3,18). U prethodno navedenom tekstu iz Poslanice Rimljanima, Pavao koristi riječ „,suobličeni“ slici, dok ovdje koristi riječ „preobraženi“ u sliku. Grčki glagol za „preobraženi“ je metamorphoumetha, prezent indikativ medij ili pasiv glagola metamorphoō. Sadašnje vrijeme u indikativu upućuje na trajnost akcije, stoga, preobraženje je proces u tijeku. Pasiv ukazuje na to da netko drugi vrši akciju, a to je Duh koji nas preobražava. Ako se pak odlučimo za medij, to ukazuje da sudjelujemo u našem preobraženju, tj. surađujemo s Duhom. Litwa se zalaže za punu snagu Pavlove izjave, protiv onih koji bi je htjeli umanjiti. On tvrdi da se preobražavamo u istu sliku koja je sam Krist te da smo „duhovno (ili čak ontološki) sjedinjeni s Kristom" (Litwa 2008, 118).

Grčka imenica za preobraženje je metamorphosis, što je porijeklo imenice "metamorfoza" u hrvatskom. ${ }^{4}$ Ta riječ koristi se kao tehnički termin u nekoliko znanstvenih područja. Zoologija daje sljedeću definiciju: „(kod insekta ili vodozemca) proces preobraženja od nezrelog oblika do odraslog oblika u dvije ili više različitih faza." ${ }^{5}$ To je paralelno razumijevanju pobožavanja kod nekih teologa, npr. Maksima Ispovjednika, koji je objašnjavao pobožavanje kao napredak ljudskih bića od nezrelog od zrelog oblika (Maximus 2015, Kindle lokacija 1841).

Klasični primjer metamorfoze iz biologije je gusjenica koja prolazi potpunu metamorfozu i pretvara se u leptira. Biološka metamorfoza je izvrsna slika teoze. Insekt koji puže i jede lišće postaje insekt koji leti i pije cvjetni nektar. I dalje ostaje insekt, ali postaje novi stvor; simbol ljepote, života i nade. Pavao izjavljuje: "Stoga, ako je tko u Kristu, on je nov stvor: staro je nestalo, novo je, evo, nastalo“ (2 Kor 5,17). Još jedna definicija metamorfoze kaže: „promjena oblika ili naravi stvari ili osobe u potpuno drugačiju." ${ }^{6}$ Predlažem da možemo promatrati pobo-

4 Ista grčka riječ transliterira se u mnoge druge jezike. Na primjer, "metamorphosis" u engleskom jeziku.

5 Oxford Dictionary, 2017, „metamorphosis”, Oxford University Press, pristupljeno 19. rujna 2017., https://en.oxforddictionaries.com/definition/metamorphosis.

6 Oxford Dictionary, 2017, „metamorphosis”, Oxford University Press, pristupljeno 19. rujna 2017., https://en.oxforddictionaries.com/definition/metamorphosis. 
žavanje koristeći obje definicije za metamorfozu: kao promjenu u duhovnoj naravi ljudskog bića i kao napredak u duhovnom rastu ljudskog bića.

Neki Pavlovi tekstovi ukazuju na to da je preobraženje u Kristovu sliku proces, kao prethodno navedeni 2. Korinćanima 3,18. Pavao također piše: „i obukoste novoga [čovjeka], koji se obnavlja za spoznanje po slici svoga Stvoritelja“ (Kol 3,10). Ovaj redak, značajan za naše proučavanje, širi je kontekst Poslanice Kološanima i govori o tome kako živjeti nov život u Kristu. Pismo potiče one, koji su iskusili novi život Božjim djelovanjem (uskrsnuti s Kristom), da nastave svoje preobražavanje vlastitim djelovanjem. Pavao zapovijeda kršćanima da traže ono što je gore, da razmišljaju o onom što je gore, da usmrte ono što je zemaljsko, da se riješe svakog lošeg ponašanja, da se obuku u vrline, da podnose jedan drugoga, da opraštaju jedan drugome, da se obuku u ljubav iznad svega, da budu vođeni Kristovim mirom, da budu zahvalni, da obiluju Božjom riječju, da poučavaju i opominju jedni druge, da pjevaju Bogu i da sve čine u Isusovo ime. Sve to mora biti dio preobraženja u sliku Stvoritelja (Kol 3,10).

Izraz „koji se obnavlja“ u Kološanima 3,10 je grčki particip anakainoumenon od glagola anakainoō. Može se prevesti kao prezent medij ili pasiv. Ako se odlučimo za medij, to stanje ukazuje na naše sudjelovanje. Ako se odlučimo za pasivno stanje, ono ukazuje da netko drugi vrši radnju na nama. Pavao koristi isti glagol u Drugoj poslanici Korinćanima 4,16, govoreći: „Naprotiv, ako se naš izvanjski čovjek i raspada, nutarnji se iz dana u dan obnavlja." U oba nam slučaja kontekst pomaže odrediti značenje. Kada je Bog čimbenik, ti oblici nazivaju se „božanski pasivi“, gdje se pasivno stanje koristi da bi se ukazalo da je Bog vršitelj radnje, a da ga se ne imenuje kao takvoga. ${ }^{7}$

Preobražavanje u Kristovu sliku počinje opravdanjem i nastavlja se posvećenjem. Kao što je spomenuto u prethodnom članku, u dijelu o Lutheru i opravdanju, gledam na opravdanje kao istinsku, ontološku promjenu u vjerniku. Opravdanje je trenutak kada vjernik nije samo proglašen pravednim nego je i učinjen pravednim. Događa se promjena u naravi ljudskog bića. Nova je narav Božji dar omogućen Kristovom žrtvom (Rim 3). Posvećenje je „proces ili rezultat Božjeg neprestanog djelovanja u vjernicima kršćanima kroz silu Svetog Duha. U protestantskoj teologiji to se odvija nakon opravdanja, i to je rast u milosti i svetosti života koji je ispunjen dobrim djelima" (McKim 1996, 247). Posvećenje znači živjeti iz naše nove naravi koju smo primili kada smo bili opravdani. S gledišta kristoze, posvećenje se može gledati kao rast u sličnosti Kristu. Drugim riječima, Božja slika u kršćanima već je obnovljena opravdanjem, dok posvećenjem nastavljamo rasti u sličnosti Bogu. Opravdanje ostvaruje trenutak obnove Božje

7 Moguće da se takvo sredstvo koristi zbog židovske uzdržljivosti od previše korištenja termina „Bog” (Wallace 2000, 189). 
slike u nama, dok posvećenje ostvaruje proces obnove naše sličnosti Bogu. Ovakvo gledište dobro se uklapa u dvije riječi koje se koriste u Postanku 1,26 - slika i sličnost. Stoga, opravdanje se može gledati kao promjena u naravi, a posvećenje kao postupna promjena u znanju i ponašanju.

Neki suvremeni teolozi ogradili su se od tradicionalnih protestantskih definicija opravdanja i posvećenja, koja ih gledaju kao odvojene i slijedne događaje. Dobar primjer je Gorman koji smatra da opravdanje i pobožavanje, prema njegovoj definiciji, opisuju istu stvarnost. On izjavljuje da „za Pavla, opravdanje je iskustvo sudjelovanja u Kristovom uskrslom životu koje se ostvaruje su-raspećem s njim“ (Gorman 2009, Kindle lokacija 399). On dalje tvrdi da je „Pavlova soteriologija najbolje opisana kao pobožavanje, ili preobražavanje u sliku kenotičkog [samoispražnjavajućeg], križolikog [samopožrtvovnog] Boga, otkrivenog u vjernom i punom ljubavi Kristovu križu, te da je Duhom omogućeno pobožavanje suština i opravdanja i svetosti“" (Gorman 2009, Kindle lokacija 1625). Stoga, „teološki rascjep između opravdanja i posvećenja je nemoguć jer Kristov duh ostvaruje i početno i daljnje suraspeće s Kristom među vjernicima..." (Gorman 2009, Kindle lokacija 1654).

U Novom zavjetu metanoia vodi do metamorfoze ${ }^{8}$ Božja riječ ima snagu promijeniti nas. Slušanjem Božje riječi, naša unutarnja osoba mijenja se prema Riječi. Mi postajemo sve ono što Riječ kaže da jesmo zbog Kristova djela spasenja i zbog našeg položaja u Kristu: spašeni, opravdani, sveti, voljeni, ispunjeni, opremljeni, ovlašteni, daroviti i poslani. Pavao to kaže na ovaj način: „Ne suobličujte se ovomu svijetu, nego se preobrazujte [metamorphousthe, od glagola metamorphoō, cf. 2 Kor 3,18] obnavljanjem [anakainōsis, cf. Kol 3,10] svoje pameti da mognete razabirati što je volja Božja, što li je dobro, Bogu milo, savršeno" (Rim 12,2). Kada obnavljamo svoj um, preobražavani smo da budemo više poput Krista ili Boga. Usvajanje Božje riječi ključno je za taj proces.

Kod Pavla, Krist je Božja slika. Svako preobraženje kršćanina je preobraženje na sliku Krista, koji je Bog. To je pobožavanje, kada se Božja slika obnavlja u ljudskom biću. „I kao što smo nosili sliku zemljanoga, nosit ćemo i sliku nebeskoga“ (1 Kor 15,49). S obzirom na Prvu Korinćanima 15 i Rimljane 5, ovo možemo gledati kao kontrast između Adama i Krista. Kao što smo nosili pokvarenu i smrtnu sliku Adama (palu sliku), nosit ćemo nepokvarenu i besmrtnu sliku Krista (slavnu sliku).

Obnova Božje slike u kršćanima također uključuje obnovu pravedne vladavine kršćana dok sudjeluju u Božjem kraljevstvu i šire ga (cf. Mt 16:19; Lk 22:29; Eph 6:12). Ovo nas povezuje s Postankom, gdje je čovječanstvo stvoreno na Božju

8 Ideja preuzeta od Franza Lippia, BLAST ministries (https://blastministries.net), s predavanja u Grazu, Austriji. 
sliku da bi vladalo Zemljom (Post 1,26.28). Krist je došao obnoviti pravednu vladavinu koju je izgubio Adam. Djela, koja je Isus činio tijekom svoje javne službe, prepoznata su kao silna $(\mathrm{Mk} 1,22) \mathrm{i}$ ispravna/dobra/pravedna (Mk 7,37). Isus je pokazao mogućnost obrata učinka grijeha i pokvarenosti kada je iscjeljivao bolesne, istjerivao zle duhove, podizao mrtve i utišao oluju. Isus je dao silu svojim učenicima, zapovjedio im da čine isto, i oni su tako postupali. Današnja Crkva slijedi primjer Krista i njegovih prvih učenika u ovome jer isti Sveti Duh istom silom i svrhom prebiva u kršćanima danas.

Nadalje, Pavlova pisma sadrže obećanja kršćanima o vladanju i suđenju svijeta. Litwa ukazuje da, kao nasljednika s Kristom,

sudbina Pavlovih obraćenika je da posjeduju sve stvari (1 Kor 3,21; Rim 8,32), sude nadljudskim silama (1 Kor 6,3) i vladaju svijetom (1 Kor 6,2; Rim 5,17) kao braća i sestre asimilirana božanskome Kristu (Rim 8,29). Oni će imati pobjedu nad „Bogom ovoga svijeta“ (1 Kor 4,4), gazeći ga pod svojim nogama (Rim 16,20) i „nadvladati“ svakog neprijatelja... (Litwa 2012, 192).

Drugim riječima, Isus obnavlja vladarsku sliku Boga u kršćanima, što je funkcijski aspekt Božje slike.

Isus obnavlja Božju sliku u kršćanima ontološki, dok sudjeluju u njegovu božanskom postojanju. Isus također obnavlja Božju sliku u kršćanima odnosno, kroz njihov odnos s Bogom, drugim kršćanima i stvorenjem. Budući da su kršćani Božja djeca i nastanjeni Bogom, oni funkcionalno žive u ljubavi i miru s drugim kršćanima te vladaju pravedno u svojim područjima utjecaja. Prema tomu, Isus ostvaruje sve aspekte obnove Božje slike u čovječanstvu, koji su opisani u prvom članku.

\section{2) Zajednički identitet s Kristom}

Po pitanju povezanosti između kršćana i Krista, Pavao iznosi tvrdnje koje se mogu ovako sažeti: ono što se dogodilo s Kristom događa se i s kršćanima. Oni sudjeluju u smrti, uskrsnuću, pa čak i u Kristovu uznesenju (duhovno, još ne tjelesno). Njihov identitet vezan je uz Kristov identitet, što pruža temelj za pobožavanje. Sada ćemo to detaljno istražiti.

U Rimljanima 6,3-8, Pavao daje sljedeće izjave. Mi smo bili kršteni $u$ Krista, što znači da smo bili pokopani s njim (synetaphēmen); bili smo sjedinjeni s njim (symphytoi) u smrti poput njegove; bit ćemo sjedinjeni s njim u uskrsnuću poput njegova; bili smo razapeti s njim (synestaurōthē); umrli smo s (apethanomen syn) Kristom; živjet ćemo s njim (syzēsomen). Većina ovih grčkih termina složeni su glagoli koji sadrže prefiks syn, koji znači "s". Doslovno možemo reći da smo bili su-ukopani, su-razapeti, su-udruženi i da su-živimo s Kristom. Pavao također kaže da nas je Bog su-uskrsnuo (synēgeiren) i su-posjeo (synekathisen) s Kristom, na nebesima $u$ Kristu Isusu (Ef 2,6). Dakle, sve to što se događa kršćanima je $s$ Kristom, u Krista i $u$ Kristu. Krist se poistovjetio s nama da bismo se mogli po- 
istovjetiti s njim. Posljedično, upoznavajući Krista, upoznajemo novog sebe. Karakterne osobine Krista karakterne su osobine onih koji su novi stvorovi u Kristu. Budući da je Kristov karakter također Božji karakter, to ukazuje na pobožavanje.

Pavlov izraz „u Kristu“ ukazuje da ne samo da vjerujemo u Krista nego također postojimo u Kristu. Taj izraz pojavljuje se 164 puta u Pavlovim pismima, prema Johnu Stottu (Stott 1). Takav način izražavanja otkriva da je Krist naš predstavnik, da smo preuzeti u Krista, što je proces pobožavanja. Na primjer, primili smo vječni život kao besplatan dar od Boga $u$ Kristu (Rim 6,23). Kada čitamo ove „u Kristu“ retke, možemo zaključiti da sve što smo primili od Boga (otkupljenje, život, oproštenje, slobodu od grijeha, ljubav) i sve što jesmo kao kršćani, naše je zbog toga što smo u Kristu. Naše postojanje u Kristu ukazuje na zajednički identitet i sudjelovanje s njim. Prema Litwi, „Dva bića mogu sudjelovati u jednom identitetu, ostajući zasebna. Ukratko, dakle, pobožavanje je sudjelovanje u božanskom identitetu (određenog) Boga. Taj određeni Bog za Pavla je onaj kojeg su on i njegove zajednice štovale kao 'Gospodina Isusa Krista'“ (Litwa 2012, 32).

Nadalje, Pavao izjavljuje: „S Kristom sam razapet. Živim, ali ne više ja, nego živi u meni Krist. A što sada živim u tijelu, u vjeri živim u Sina Božjega koji me ljubio i predao samoga sebe za mene" (Gal 2,19b-20). Tema poistovjećivanja s Kristom javlja se ponovo. Pavao implicira smrt svoje unutarnje osobe i život Kristove osobe u njemu (cf. Rim 6,6-11). Sudjelovanje u Kristovoj osobi i sudjelovanje u Kristovu životu snažan je argument za kristozu, a time i teozu. Gorman također ističe koncept križolikosti u Pavlovu pobožavanju: „Za Pavla, biti jedno s Kristom je biti jedno s Bogom; biti poput Krista je biti poput Boga; biti u Kristu je biti u Bogu. U najmanju ruku, to znači da je za Pavla križolikost - suobličavanje razapetom Kristu - zapravo bogolikost ili pobožavanje“ (Gorman 2009, Kindle lokacija 57).

Razmjena života s Kristom važan je koncept u pobožavanju zato što uključuje napuštanje našega pokvarenoga ljudskog života i primanje Kristova božanskog života. Pavlova formula razmjene nalazi se u nekoliko njegovih tekstova. On govori o Kristu koji je proklet za nas, tako da bismo bili blagoslovljeni: „Krist nas otkupi od prokletstva Zakona, postavši za nas prokletstvom - jer pisano je: Proklet je tko god visi na drvetu - da u Kristu Isusu na pogane dođe blagoslov Abrahamov: da Obećanje, Duha, primimo po vjeri“ (Gal 3,13-14). Govori o Kristu, koji postaje grijehom, da bismo mi postali pravedni: „Njega koji ne okusi grijeha Bog za nas grijehom učini da mi budemo pravednost Božja u njemu" (2 Kor 5,21). Govori o Kristu koji postaje siromašan, da bismo mi postali bogati: „Ta poznate darežljivost Gospodina našega Isusa Krista! Premda bogat, radi vas posta siromašan, da se vi njegovim siromaštvom obogatite" (2 Kor 8,9). I govori o sebi, a time i o svim kršćanima, kako razmjenjujemo svoje živote s Kristom: „Živim, ali ne više ja, nego živi u meni Krist" (Gal 2,20a). 
Prema Pavlu, trebamo Krista staviti na sebe i ponašati se poput Krista. To se ponekad naziva pobožavanje moralnom asimilacijom (Litwa 2012, 217). Pri krštenju, već smo stavili na sebe Krista (enedysasthe, aorist indikativ medij, Gal 3,27) i, dok živimo, zapovjeđeno nam je da ponovo stavimo na sebe Krista (endysasthe, aorist imperativ medij, Rim 13,14). Trebamo imitirati Pavla kako on imitira Krista (1 Kor 11,1). Također, trebamo imitirati Boga, slijedeći Kristov primjer (Ef 5,1-2). Mnogo različitih Pavlovih zapovjedi o ponašanju temelje se na imitiranju Boga, imitiranju Krista i življenju novog života. Dugački odlomci o novom životu u Kristu nalaze se u Rimljanima 12, Kološanima 3 i Efežanima 5. Drugim riječima, možemo surađivati u našem preobraženju na Kristovu sliku, ponašajući se poput njega.

Iz Pavlovih pisama možemo razlučiti na koje smo načine već preobraženi, na koje načine bivamo preobražavani i na koje ćemo načine biti preobraženi. Pavao govori da se ljudska bića sastoje od tri dijela: duha, duše i tijela (1 Sol 5,23). ${ }^{9}$ Ljudski je duh pobožen u trenutku kada osoba postane kršćaninom jer tada postaje sjedinjena i ispunjena s Božjim Duhom. Duša (um, osjećaji i volja) ulazi u proces pobožavanja učeći razmišljati, osjećati i donositi odluke na Božje načine. Tijelo može primati božansko iscjeljenje omogućeno Kristovim križem, ${ }^{10}$ ali ono je raspadljivo i smrtno zbog pada. Tijelo mora umrijeti, ali će biti uskrsnuto i poboženo pri Kristovu drugom dolasku.

Drugi Pavlovi tekstovi impliciraju da su ljudi ili u Adamu ili u Kristu. Pavao čak naziva Krista „posljednji Adam“ (1 Kor 15,45). Biti u Adamu implicira da ljudi dijele Adamov identitet i prokletstva. Čovječanstvo je palo, pokvareno, osuđeno i smrtno. Biti u Kristu implicira da kršćani dijele Kristov identitet i blagoslove. Podignuti su u novi život. Spašeni su, sveti, opravdani i besmrtni. Uživaju u bliskom odnosu s Bogom. Pavao nastavlja svoju misao o Adamu i Kristu kao o posljednjem ili drugom Adamu: „Prvi je čovjek od zemlje, zemljanin; drugi čovjek - s neba. Kakav je zemljanin takvi su i zemljani, a kakav je nebeski takvi su i nebeski“ (1 Kor 15,47-48). Time ponovo potvrđuje da je kršćanski identitet temeljen u Kristu i dijeljen s Kristom.

\section{3) Sjedinjenje s Kristom}

U svom dopisivanju s korintskom Crkvom, Pavao izjavljuje: „A tko se združi s Gospodinom, jedan je duh“ (1 Kor 6,17). Kršćanin je sjedinjen (kollōmenos, prezent particip medij glagola kollaō, što doslovno znači „slijepljen zajedno“) s Kristom i jedan je duh s Kristom. Litwa predlaže: „Pneuma 'koji živi u' (Rim

9 U teološkoj antropologiji, ovo se gledište naziva trihotomizam od grčke riječi trihotomia, "podjela na troje".

10 "Njegovim smo ranama iscijeljeni" (Iz 53,5; 1 Pt 2,24). 
8,9; cf. 1 Kor 3,16; 6,19) nutrini vjernika u najmanju ruku ukazuje na visoku razinu integracije božanske i ljudske osobe" (Litwa 2012, 162). Maksim Ispovjednik govorio je o ovome perihoretičkom sjedinjenju. Perihoreza je „termin koji se koristi u teologiji Trojstva da bi ukazao na blisko sjedinjenje, međusobno prebivanje ili međusobno prožimanje triju člana Trojstva. Također, koristi se vezano uz dvije Kristove naravi“ (McKim 1996, 207). Međutim, taj koncept također znači „perihorezu Boga i vjernika, čiji se prototip nalazi u perihorezi hipostatskog sjedinjenja u osobi Logosa..." (Vishenvskaya 2008, 132). Drugim riječima, u kršćanima se nalazi blisko sjedinjenje, prebivanje i prožimanje ljudske i božanske naravi.

\section{4) Posinjenje i pobožavanje}

Teme identiteta i sjedinjenja dovode nas do još jedne ideje, posinjenja, što znači da ljudi mogu postati Božja djeca. Koncept posinjenja istaknut je u Pavlovim poslanicama. Efežanima 1,5 kaže da nas je Bog „predodredio po Isusu Kristu za svoje sinove“, dok 5,1 kaže: „Budite, dakle, nasljedovatelji Boga, kao ljubljena djeca“. Prva izjava govori o našem identitetu Božje djece, dok druga govori o našem ponašanju koje se temelji na tom identitetu. Kao što sam ranije raspravljao, dijeljenje identiteta s Bogom, djece s Ocem, omogućava konstrukciju za pobožavanje. Ovdje vidimo obiteljsku usporedbu kojom se opisuje duhovna stvarnost.

U fizičkom svijetu, naš je identitet oblikovan prema našim roditeljima. Dijelimo identitet s roditeljima, ljudima koji su nas tjelesno začeli i porodili. Djeca nose gene svojih roditelja. Duhovno govoreći, također nam je dan identitet prema našem roditelju - Bogu Ocu. Duhovno smo nosili samo Adamove gene, ali sada nosimo gene našeg Boga Oca. Pavao izričito govori o srodnosti Boga, Isusa i kršćana. „Te metafore srodnosti izražavaju vrstu povezanosti koja se s pravom naziva 'genetskom' jer ima veze s $\gamma \varepsilon$ ćvo $\varsigma$-om, s rasom ili klasom u koju dva entiteta pripadaju. Ukratko, Krist i vjernici, kao rodbina, pripadaju istoj klasi bića, a to su božanski 'sinovi Božji'“ (Litwa 2012, 12).

U poslanicama Galaćanima i Rimljanima Pavao detaljnije objašnjava metaforu posvojenja.

A kada dođe punina vremena, odasla Bog Sina svoga: od žene bi rođen, Zakonu podložan da podložnike Zakona otkupi te primimo posinstvo. A budući da ste sinovi, odasla Bog u srca vaša Duha Sina svoga koji kliče: "Abba! Oče!" Tako više nisi rob nego sin; ako pak sin, onda i baštinik po Bogu (Gal 4,4-7).

Svi koje vodi Duh Božji sinovi su Božji. Ta ne primiste duh robovanja da se opet bojite, nego primiste Duha posinstva u kojem kličemo: "Abba! Oče! Sam Duh susvjedok je s našim duhom da smo djeca Božja; ako pak djeca, onda i baštinici, baštinici Božji, a subaštinici Kristovi, kada doista $s$ njime zajedno trpimo, da se zajedno s njime i proslavimo (Rim 8,14-17). 
Krist nas je otkupio od ropstva pod starozavjetnim zakonom da bismo postali Božja djeca. Zbog Kristova djela primili smo Svetog Duha koji nas čini Božjom djecom i koji nam obznanjuje da smo Božja djeca. To što smo njegova djeca znači da smo Božji nasljednici zajedno s Kristom. Biti Božje dijete i nasljednik implicira pobožavanje - ono smo što je on, imamo ono što on ima, možemo činiti ono što on čini. Dijelimo identitet s Kristom (su-nasljednici, synkleronomoi). Dijelimo sudbinu s Kristom i imitiramo ga kroz patnju. Galaćanima 3,26 potvrđuje: „Uistinu, svi ste sinovi Božji, po vjeri u Kristu Isusu“.

U Efežanima Pavao tvrdi da „po naravi bijasmo djeca gnjeva kao i drugi“ $(2,3)$. Također, piše: „Da, nekoć bijaste tama, a sada ste svjetlost u Gospodinu: kao djeca svjetlosti hodite - plod je svjetlosti svaka dobrota, pravednost i istina“ $(5,8-9)$. Ova promjena naravi je radikalna i značajna; od tame u svjetlost, od djece gnjeva u djecu svjetlosti. Pobožavanje počinje promjenom naravi u ljudskom biću; od pale, zatamnjene naravi u Adamu do obnovljene, prosvijetljene naravi u Kristu. Nastavlja se načinom života koji je ukorijenjen u novoj naravi koji se manifestira čineći što je „dobro i pravedno i istinito“. To je Božji karakter i Kristov karakter. Kada kršćani čine što je dobro i pravedno i istinito, time pokazuju pobožavanje, promjenu naravi i ponašanja u skladu s Božjom slikom.

\section{5) Eshatologija i pobožavanje}

Pavao govori o eshatološkim događajima po pitanju tijela koji se mogu smatrati završetkom pobožavanja. Do sada smo raspravljali o duhovnom pobožavanju, o našoj nutarnjoj osobi koja postaje poput Boga. Međutim, Pavao također izjavljuje da će Krist preobraziti [metashēmatisei, futur indikativ aktiv glagola metashēmatizō] tijela kršćana te ih učiniti suobličenima [symmorphon, pridjev] svome slavnom tijelu (Fil 3:21). U Prvoj Korinćanima 15, Pavao govori o Kristovu uskrsnuću, o uskrsnuću mrtvih i detaljno o uskrslom tijelu (15,35-55). On tvrdi: „I kao što smo nosili sliku zemljanoga, nosit ćemo i sliku nebeskoga“ (1 Kor 15,49) i „mrtvi će uskrsnuti neraspadljivi i mi ćemo se izmijeniti [allagēsometha, futur indikativ pasiv glagola allassō]. Jer, ovo raspadljivo treba da se obuče u neraspadljivost i ovo smrtno da se obuče u besmrtnost (1 Kor 15,52b-53). U Drugoj Korinćanima Pavao se ponovo bavi ovom temom kada govori o našem tijelu kao zemaljskom šatoru i o našoj čežnji da se ono zamijeni Božjim vječnim, nebeskim prebivalištem (2 Kor 5,1-2). Njegova je nada „da bi život progutao ono što je smrtno" (2 Kor 5,4). Nepokvarljivost i besmrtnost prožet će čitavo ljudsko biće. Pobožavanje će biti završeno. Stoga, pobožavanje je „neprestani proces od zemaljskog začetka do eshatološkog završetka, no očito je da ima dvije faze, ili dimenzije, temporalnu i eshatološku" (Gorman 2015, Kindle lokacija 6945).

Gorman smatra da bi pobožavanje mogao biti najbolji izraz za Pavlovu antropologiju i soteriologiju. Pavlovu Poslanicu Rimljanima naziva „prvom kršćan- 
skom raspravom o pobožavanju“ (Gorman 2011, 13). Ljudsko stanje predstavlja kao ono kojem nedostaje pravednost i slava. Božje je rješenje dar pravednosti i slave ljudima u Isusu Kristu da bi stvarali zajednice pravednosti i slave koje Duh osnažuje da očituju kristoliku pobožnost (Gorman 2011, 20-32). „Za Pavla, rješenje za ljudsko stanje grijeha i smrti, nepravednosti i ne-slave, novi je i vječni život sudjelovanjem u Kristu. To sudjelovanje ostvaruje etičku i eshatološku transformaciju koju ljudska bića trebaju" (Gorman 2011, 23).

Litwa $(2012,5)$ daje opis pobožavanja u Pavlovoj teologiji:

Za Pavla, Isus Krist posreduje ljudsku transcendentnost kao onaj koji je i sam „rođen od žene“ (Gal 2,4) te zatim „postavljen Božjim sinom“ $i$,Gospodarem“ (Rim 1,4; Fil 2,9-11; cf. Djela 2,36). Svojim uskrsnućem Krist je već pokazao univerzalnu moć i besmrtnu tjelesnost koja je proleptički ujedinila nebo i zemlju, ljudsko i božansko. Pavao predviđa "proslavljenje“ onih koji su zbog grijeha prvog Adama lišeni Božje slave (Rim 8,29; 3,23). On propovijeda da je božanski duh, ili Kristova pneuma, otpuštena u tijelo onih koji su „u Kristu“, što je zalog za njihovu novu tjelesnost (Rim 8,1-11; 2 Kor 4,16-17). Kroz Kristovu pneumu, ljudi imaju obećanje dosezanja transcendencije besmrtnog, nepokvarljivog (i stoga nadljudskog) Kristova stanja. Kao oni koji su asimilirani u moć i besmrtnost božanskog Krista, takva ljudska bića imaju moć da se nazivaju „djeca Božja“ (Rim 8,15-16) i posjednici svega (Rim 8,32; 1 Kor 3,21-23). Jedan način da se razumije ovaj skup ideja je kroz kategoriju pobožavanja - autohtonu kategoriju koja je prožimala Pavlovu kulturu.

Ovaj Litwin sažetak u potpunosti je prožet djelima Isusa Krista. Pokazuje ključnu važnost Krista za pobožavanje ljudskih bića. Što se tiče pobožavanja, sve se događa zbog onoga što je učinio Krist i sve se događa po Kristovu duhu, onima koji su u Kristu, da bi dosegli Kristovo božansko stanje.

\section{Pobožavanje u Ivanovoj i Petrovoj teologiji}

\section{Novo rođenje i pobožavanje}

Da sažmem svoju raspravu o Pavlovoj teologiji, prije svega, bavio sam se temama obnove, identiteta, sudjelovanja, kristoze, posinjenja, sjedinjenja i eshatologije utoliko ukoliko su povezane s pobožavanjem. Kad se okrenemo Ivanovim spisima, susrećemo se s temom novog rođenja. Nijedna od blagodati koju Pavao opisuje ne može se primiti bez novog rođenja. Novo rođenje je preduvjet ili početna točka pobožavanja. Pavao koristi terminologiju novog rođenja u Galaćanima 4, u ilustraciji s Izakom i Išmaelom. „Vi ste, braćo, kao Izak, djeca obećanja. I kao što je onda onaj po tijelu rođeni progonio onoga po duhu rođenoga, tako je i sada" (Gal 4,28-29). Pavao ovdje suprotstavlja pobornike židovstva (rođeni po tijelu) i kršćane (rođeni po Duhu). Ivan će više toga govoriti o konceptu novog rođenja. 
U Ivanu 1, postati Božjim djetetom povezano je s rođenjem od Boga: „A onima koji ga primiše podade moć da postanu djeca Božja: onima koji vjeruju u njegovo ime, koji su rođeni, ne od krvi, ni od volje tjelesne, ni od volje muževlje, nego - od Boga“" (Iv 1,12-13). U Ivanu 3, pisac nam prenosi Isusove riječi u vezi novog rođenja: „Zaista, zaista, kažem ti: ako se tko ne rodi iz vode i Duha, ne može ući u kraljevstvo Božje" (Iv 3,5-6). Novo rođenje postavljeno je kao preduvjet za ljudska bića. Ono se događa ljudskom duhu, a obavlja ga Duh Sveti. U Prvoj Ivanovoj poslanici, izraz „rođen od Boga“ (ek tou Theou gegennētai) ili „rođen od njega [Boga]" odnosi se na kršćane sedam puta. ${ }^{11}$ Prema Prvoj Ivanovoj, oni koji su rođeni od Boga čine što je ispravno $(2,29)$, ne griješe $(3,9$ i 5,18$)$, ljube druge $(4,7)$, vjeruju da je Isus Krist $(5,1)$ i pobjeđuju svijet $(5,4)$. Ivan izjavljuje da se te osobine prenose izravno od Boga u one koji su rođeni od njega. Oni koji čine što je ispravno čine tako jer je Bog pravedan $(2,29)$. Oni koji ne griješe čine tako jer je Božje sjeme u njima $(3,9)$. Oni koji vole čine tako jer je Bog ljubav $(4,7)$. Ljudi koji su rođeni od Boga nasljeđuju Božje osobine.

U fizičkom svijetu svoj identitet stječemo rođenjem. U duhovnom svijetu svoj identitet stječemo ponovnim rođenjem. $U$ fizičkom svijetu dijelimo identitet svojih zemaljskih roditelja jer su nas oni začeli i rodili. Primamo obiteljsko ime svojih roditelja, kao i svoje osobno ime. Povezani smo krvlju i dijelimo isti DNK. Ponekad, ako je srodnost roditelja i djeteta dovedena u pitanje, ono se provjerava pomoću DNK testa.

U duhovnom je svijetu Bog Otac taj koji nas rađa. Kada smo rođeni od njega, primamo Božji duhovni DNK. Mogli bismo reći da primamo njegove duhovne gene. Božji duhovni geni, da tako kažemo, proizvode svetost, pravednost, milosrđe, ljubav, radost i mir. Međusobno smo povezani Kristovom krvlju. Božja smo djeca i pridruženi smo njegovoj obitelji. On je naš Otac. Premda primamo ovaj zajednički identitet, i dalje istovremeno zadržavamo svoju individualnost.

Petar govori o novom rođenju dva puta u prvom poglavlju svoje prve poslanice. Na početku izjavljuje da nas Bog „po velikom milosrđu svojemu uskrsnućem Isusa Krista od mrtvih nanovo rodi ${ }^{12}$ za životnu nadu" $(1 \mathrm{Pt} 1,3)$. Bog je onaj koji nam je omogućio da budemo ponovo rođeni, kroz Kristovo uskrsnuće. Petrova je misao slična Pavlovoj u Rimljanima 6. Možemo imati novi život jer je Krist ustao od mrtvih. Njegovo uskrsnuće omogućava naše novorođenje. Ono što se dogodilo s njim, dogodilo se i s nama. Podignuti smo u novi život. Naš identitet i život povezan je s Kristovim identitetom i životom.

11 Jedanput „rođen od njega [Boga]“ i šest puta „rođen od Boga“ odnosi se na kršćane, a jedanput „rođen od Boga“ odnosi se na Krista (1 Iv 5,18b).

12 Grčki anagennēsas, aorist particip aktiv glagola anagennaō (nanovo roditi). 
Kasnije u istom poglavlju Petar izjavljuje: „Ta nanovo ste rođeni, ${ }^{13}$ ne iz sjemena [sporas] raspadljiva, nego neraspadljiva: riječju Boga koji živi i ostaje“ (1 Pt 1,23). Začeti smo i rođeni od sjemena koje je Božja riječ. Kada Ivan govori o našem rođenju od Boga, on koristi drugačiji izraz za Božje sjeme - sperma (1 Iv $3,9)$. U fizičkom svijetu, muškarac otpušta svoje sjeme u maternicu žene i začinje se i rađa novi život. U duhovnom svijetu, Bog otpušta svoju riječ u naš duh i začinje se i rađa novi život (Vincent 2008, 36). Vincent objašnjava rezultat: „Na taj način Bog u nama stvara novu osobu koja ima našu osobnost, ali također ima Božju narav i život. Kada Bog završi svoje dobro djelo u nama, naša ljudskost bit će prožeta Božjom nepokvarljivom naravi (Vincent 2008, 36). Ti su koncepti važni za teozu jer pokazuju duhovno naslijeđe, identitet i sličnost između kršćana i Boga.

\section{Ivanovo pobožavanje: božanski život u vjernicima}

Naposljetku, što se tiče božanskog života u kršćanima, razmatramo sljedeće Ivanove izraze: „tko vjeruje u Sina, ima vječni život (Iv 3,36$)$ i „tko ima Sina, ima život" (1 Iv 5,12). U Ivanovoj kristologiji vječna je Riječ postala tijelom da bi donijela božanski život ljudima (Russell 2004, 6). „U njemu bijaše život“ (Iv 1,4), „da svaki koji vjeruje u njega ima vječni život“ (Iv 3,15). On je život (Iv 14,6) i on daje vječni život (Iv 17,2). Ivan piše o božanskom životu koji je na raspolaganju kršćanima kroz Krista i u Kristu. On to naziva „vječni život“ ili samo „život“ ili "život u izobilju“. ${ }^{14}$

Ponekad kršćanska teologija govori o vječnom životu koji počinje nakon naše smrti ili nakon uskrsnuća naših tijela. Kod Ivana, međutim, vječni život kršćani posjeduju sada. Vječni život nije samo kvantiteta nego i kvaliteta života. ${ }^{15}$ To je Kristov život. To je božanski život. Stoga, ako posjedujemo božanski život, tada smo u procesu pobožavanja.

Ivan kaže da vjernici mogu primiti Duha (Iv 7,38-39) i biti sjedinjeni s Ocem i Sinom (Iv 14,20; 15,5; 17,21). Otac i Sin mogu se nastaniti u vjerniku (Iv 14,23). Ivan nam kaže: „... kakav je on, takvi smo i mi u ovom svijetu“ (1 Iv 4,17). To ukazuje na jedinstvo kršćana s Bogom, sudjelovanje u božanskom životu i poistovjećenje s Kristom, a to su sve elementi pobožavanja.

13 Grčki anagegennēmenoi, perfekt particip medij ili pasiv glagola anagennaō (nanovo roditi).

14 „Vječni život” (Iv 3,15.16.36; 5,24.39; 6,27.40.47.54; 10,28; 12,50; 17,2.3; 1 Iv 2,25; 3, 15; 5,11.13). “Život” (Iv 5,40; 6,53; 1 Iv 3,14; 5,12). “Život u izobilju” (Iv 10,10).

15 Vidi, na primjer, Roberts 1963, 186-193. 


\section{Zaključak}

Nakon ispitivanja novozavjetnih učenja povezanih s pobožavanjem, otkrili smo da Pavao govori o obnovi Božje slike u ljudima kroz nekoliko mehanizama: preobražavanje u Kristovu sliku; dijeljenje identiteta s Kristom; prebivanje u Kristu; imitiranje Krista; jedinstvo s Kristom; biti Božjom djecom u Kristu; i buduće tjelesno preobraženje u skladu s Kristovim proslavljenim tijelom. Petar i Ivan govore o novom duhovnom rođenju, početnoj točki pobožavanja, što nam omogućava da iskusimo sve drugo. Ivan govori o božanskom životu koji sada djeluje u nama i o našem sjedinjenju s Bogom. On nas vidi kao posjednike i sudionike vječnog života.

Osoba i djelo Isusa Krista i Duha Svetoga ključni su za pobožavanje. Teoza „je moguća samo zbog Utjelovljenja, što je čovještvu stavilo na raspolaganje božanstvo, i kroz Duha Svetoga, koji to prenosi ljudima“ (Olson 2007, 190). Krist, koji je bio Bog od vječnosti, utjelovio se te posjedovao i manifestirao dvije naravi - ljudsku i božansku. „Čak i čovještvo Isusa Krista, koje je bilo prosvijetljeno unijom s božanskim, ostalo je ograničeno i dio stvorenja. No bilo je poboženo sjedinjenjem $s$ božanskim, što znači da je primilo besmrtnost i nadnaravna svojstva koja pripadaju isključivo Bogu... Isto vrijedi, u nekoj mjeri, za svakog sveca“ (Olson 2007, 190).

Kristova smrt i uskrsnuće nisu omogućili samo oproštenje grijeha nego i novi život u ljudskim bićima. Krist je omogućio ljudima da postanu nova stvorenja. Svojim utjelovljenjem, životom, smrću, uskrsnućem i uznesenjem, ostvario je otkupljenje i pomirenje čovječanstva te omogućio nastanjivanje Svetog Duha u ljudima. Otac je onaj koji je poslao Duha. Stoga, čitavo je Trojstvo uključeno u pobožavanje. Premda se u Novom zavjetu nigdje ne koristi riječ „pobožavanje“, koncept je često artikuliran u kanonu. Kao što Litwa zamjećuje: „,iako Pavao izbjegava konkretan vokabular pobožavanja - terminologija njegove soteriologije odavno ukazuje na to da je određeni oblik pobožavanja na djelu u njegovoj misli“ (Litwa 2012, 10). Gorman isto tako potvrđuje da „Pavlova je soteriologija najbolje opisana kao pobožavanje“ (Gorman 2009, Kindle lokacija 1625).

U konačnici, Sveti Duh je taj koji omogućava pobožavanje onima koji vjeruju u Krista. Oni koji su kršteni u Isusa Krista mogu primiti Duha, a Duh se može nastaniti u njima. Sveti Duh zatim nastavlja preobražavati one koje nastanjuje. Litwa ustvrđuje da „božanski element dominira smrtnim tijelom i postaje pravo ja... [i] otkupljeni su poboženi božanskom pneumom, što određuje njihov identitet" (Litwa 2012, 163). Nadalje, kršćani nisu samo nastanjeni Bogom nego i oni prebivaju u Bogu.

Krist kao reprezentativni čovjek obuhvaća sve vjernike u sebi i pobožava ih svojim epohalnim djelima (poslušnost, smrt, uskrsnuće) jer je on sam božanski. 
Vjernici sudjeluju u tom pobožavanju vjerom u Krista, usvajajući ono što Novi zavjet opisuje kao učinke Kristovih djela, obnavljajući svoje umove u skladu s (Kristovom) Riječi i, također, imitirajući Krista. Prebivanje Boga u kršćanima, prebivanje kršćana u Bogu i međusobno sjedinjenje, ili prožimanje, predlažu da više nismo pala ljudska bića, nego da smo počeli s pobožavanjem. Taj će se proces završiti pri drugom Kristovu dolasku kada primimo slavna, besmrtna, nepokvarljiva tijela.

\section{Prema oblikovanju evanđeoske doktrine o pobožavanju}

U prethodnom sam članku raspravljao o pobožavanju kao biblijski utemeljenoj teologiji koja je bila povijesno poduprta velikim kršćanskim tradicijama. U prvom sam dijelu tog članka predstavio glavne biblijske tekstove za pobožavanje i raspravljao na koji način doprinose doktrini. To obuhvaća Postanak 1,26-27, gdje je Bog načinio ljude na svoju sliku i sebi slične. Kao ljudi, dijelimo Božju narav jer smo duhovna, razumna, odnosna i vladajuća bića. Zatim sam okrenuo na Psalam 82,6-7, gdje Bog izričito spominje ljude kao „bogove“ i „Božju djecu“, i govorio sam o ljudskoj vlasti da sudi i izvršava pravdu. Nakon toga sam raspravljao o tekstu u Ivanu 10,34-36, gdje Isus citira Psalam 82, potvrđujući da su ljudi nazvani „bogovima“. Također, obradio sam Drugu Petrovu poslanicu 1,4 i mogućnost da kršćani sudjeluju u božanskoj naravi.

U drugom dijelu prvog članka pokazao sam da je pobožavanje povijesna doktrina. Koncept pobožavanja prisutan je od vremena rane Crkve pa sve do moderne Crkve. Ono je bilo prisutno, u različitim stupnjevima, kroz sva povijesna razdoblja kršćanstva: rano poslijeapostolsko razdoblje, patrističko razdoblje, srednjovjekovno razdoblje, reformaciju i moderno doba. U nekim je kršćanskim krugovima bilo dominantno, a u drugima marginalno, no u svakom slučaju, sljedivo kroz povijest kršćanstva. Tamo gdje je bilo dominantno, razvilo se u doktrinu; tamo gdje je bilo marginalno, ostalo je samo konceptualno. Za evanđeosko kršćanstvo važno je da su elementi pobožavanja pronađeni i kod prethodnika - u reformaciji, radikalnoj reformaciji i pokretima probuđenja.

U prvom sam dijelu ovog članka istraživao na koji način se pobožavanje pojavljuje u novozavjetnoj teologiji i raspravljao o mnogim tekstovima koji doprinose doktrini pobožavanja u Pavlovim, Petrovim i Ivanovim spisima. Istaknuo sam da utjelovljenje Isusa Krista, božanskog bića koje postaje ljudsko, pruža nadu da se ljudska narav može sjediniti s božanskom naravi. U Pavlovoj teologiji mogućnost obnove Božje slike u ljudskim bićima nudi se kroz Isusa Krista, koji je savršena slika Boga. Pavao izričito tvrdi da je Božja svrha za nas da budemo suobličeni, ili preobraženi, u sliku Krista. Stoga, teoza je jedna vrsta kristoze. Pavao 
ističe da dijelimo Kristov identitet i sudbinu. Sudjelujemo u Kristovoj smrti, uskrsnuću i uznesenju. Postojimo u Kristu i stavljamo ga na sebe. To nas sjedinjuje s Kristom u duhu, što je jedinstvo i prožimanje ljudske i božanske naravi u nama. U Pavlovim spisima, mi smo Božja djeca po Kristu i u Kristu. Pavao govori o radikalnoj promjeni naravi u nama - iz tame u svjetlost, iz pale naravi u Adamu do obnovljene naravi u Kristu. On naviješta eshatološko ispunjenje naše kristoze (a time i teoze), kada će naša tijela biti preobražena u skladu s Kristovim slavnim tijelom.

Kod Petra i Ivana ključni događaj naziva se novo rođenje. Biti rođen od Boga početna je točka pobožavanja. Kada smo rođeni od Boga, nasljeđujemo Božje osobine i poput Boga smo. Nosimo njegove duhovne gene koji zatim razvijaju njegove duhovne osobine u nama, što se pokazuje u ponašanju koje odražava Kristov karakter. Ivan opetovano govori o vjernicima kao onima koji posjeduju božanski život zbog svoje vjere u Krista. Petar nas podsjeća da sudjelujemo u božanskoj naravi, a to znači da možemo sudjelovati u Božjem životu i svojstvima.

Pobožavanje je teološko područje jer je povezano s drugim važnim kršćanskim doktrinama. U ovom smo članku vidjeli da pobožavanje ulazi u interakciju s doktrinama kao što su antropologija, kristologija, pneumatologija, spasenje, opravdanje, posvećenje i eshatologija. Razvijeno razumijevanje pobožavanja može razjasniti ideje u tim drugim područjima. Corbin-Reuschling kaže da pobožavanje "nosi implikacije za druge teološke okvire: svrhe stvorenja, narav ljudskosti, utjecaj grijeha, kristologiju, uključenost Trojstva u djelo otkupljenja, kršćansko oblikovanje, oblik i misiju Crkve, sakramente i eshatološku nadu“ (Corbin-Reuschling 2014, 276). Gorman tvrdi: „Kenoza, opravdanje, suobličenje križu, teoza - sve je to dio jednoga jer se sve odnosi na jednu soteriološku stvarnost nastanjivanja u križolikom Bogu koji se otkriva u Kristu po sili Duha, od prvog trenutka vjere do eshatološkog cilja potpune slave“ (Gorman 2009, Kindle lokacija 1708).

Pobožavanje je evangelički koncept jer objašnjava Evanđelje i Spasenje. Ono bi trebalo biti prihvaćeno kao evanđeoska doktrina jer sadrži radosnu vijest o Isusu Kristu, obuhvaća čitavu priču o Bogu i čovječanstvu (od stvaranja do obnovljenog stvorenja), promiče glavnu Božju svrhu za čovječanstvo, opisuje ulogu Oca, Sina i Duha u obnovi čovječanstva i fokusira se na odnos između Boga i čovjeka. Evanđeosko kršćanstvo stavlja naglasak na autoritet Biblije, na osoban odnos s Bogom u Isusu Kristu i na širenje Evanđelja. Autoritet Biblije očit je u konceptu pobožavanja jer se doktrina temelji na biblijskim učenjima i biblijskoj narativi. Osoban odnos s Bogom ključan je za pobožavanje jer se teoza vjernika može dogoditi samo kroz osoban odnos u kojem se vjernik progresivno preobražava na Kristovu sliku. Naposljetku, poučavanje pobožavanja može biti odličan 
alat za širenje radosne vijesti jer ono govori radosnu vijest, čitavu priču, o obnovi čovječanstva i svega stvorenja.

\section{Oblikovanje doktrine pobožavanja za evanđeosku teologiju}

Moja dva članka o pobožavanju identificirali su brojne doktrinarne komponente i pružili opravdanje za uvrštavanje pobožavanja u evanđeosku teologiju. Sada ću napraviti pregled tih doprinosa, a zatim završiti ovaj članak s nekoliko komentara o dobrobitima ove nauke.

Pobožavanje je postajati poput Boga, obnova Božje slike i sličnosti Bogu u kršćanima. Pobožavanje se događa kroz Kristovo djelo i kroz proces kristoze. Krist nas spašava, u Kristu smo usvojeni kao Božja djeca, primili smo Kristov božanski život i preobražavamo se na Kristovu sliku. Kristoza se događa kroz djelovanje Svetog Duha u vjerniku, kroz regeneraciju i transformaciju.

Bog je stvorio ljudska bića na svoju sliku i sličnost. Bili su poput Boga strukturno ili suštinski (duhovni, razumni, besmrtni, nepokvareni, slavni), odnosno (stvoreni za blizak odnos s Bogom, drugim ljudima i stvorenjem) i funkcijski (stvoreni da vladaju zemljom kao Božji predstavnici). Ljudi su pokvarili tu sliku svojim padom. Njihova je narav bila narušena, njihovi odnosi pokvareni (s Bogom, drugim ljudima i stvorenjem) i postali su nepravedni vladari. U Starom smo zavjetu vidjeli neke primjere djelomične obnove. To se uglavnom događalo kroz pojedince koje je Bog pozvao i pomazao svojim Duhom za određeni zadatak tijekom razdoblja vjernosti njegova izabranog naroda. Međutim, vrijeme obnove bilo je prorokovano, da će se ostvariti u potpunosti kroz budući novi savez, dolazak Mesije i izlijevanje Svetog Duha.

Kristovo utjelovljenje pruža temelj i nadu za pobožavanje. To što je božansko biće postalo ljudskim bićem otvorilo je mogućnost da ljudska bića mogu biti pobožena. Budući da se božanska narav pridružila ljudskoj naravi u Kristu, ljudska narav može se pridružiti božanskoj naravi u ljudskim bićima. Kristova kenoza omogućava kršćansku teozu.

Kroz život, smrt i uskrsnuće Isusa Krista, obnova Božje slike u ljudima postala je dostupna. Krist je savršena slika Boga i kršćani se mijenjaju na njegovu sliku. Ta transformacija počinje opravdanjem kada su oni koji povjeruju u Krista učinjeni pravednima i primaju stvarnu promjenu u svom biću. Transformacija se nastavlja posvećenjem u kojem se sličnost Bogu postupno obnavlja u njima.

Budući da vjernici postaju Božja djeca u Isusu Kristu, njihov odnos s Bogom uspoređuje se s odnosom roditelj - dijete. S obzirom na to da su vjernici učinjeni pravednima, pravedna vladavina za koju je čovječanstvo bilo stvoreno postaje opet moguća. Kršćani se odnose s ljubavlju i pravednošću prema drugim ljudi- 
ma, tražeći da iscijele i obnove druge koji su u njihovu krugu odnosa. Počinju brinuti za Zemlju, što je dio njihova izvornog, Bogom danog poziva u Postanku. ${ }^{16}$ Stoga, Isus obnavlja Božju sliku u kršćanima u svim aspektima - ontološkom, odnosnom i funkcijskom. Obnova slike je sveobuhvatna, ali ne još potpuna. Obnova nastavlja progresivno napredovati u onima koji su učenici, kako napreduju u svetosti kroz svoj odnos s Bogom. Obnova će biti u potpunosti ostvarena kada prime proslavljeno tijelo, da bi živjeli i vladali s Kristom u vječnosti. Pobožavanje će biti potpuno.

Pobožavanje je sudjelovanje u Kristu, u njegovu božanskom identitetu, životu i sudbini. Oni koji vjeruju u njega i kršteni su u njega, duhovno umiru s njim i uskrsavaju s njim u novi život. Primaju Kristov božanski život. Prelaze iz Adamova prokletstva u Kristov blagoslov, iz grijeha i smrti u svetost i život, iz pokvarenosti i smrtnosti u nepokvarenost i besmrtnost. Postaju jedan duh s Kristom, gdje se ljudska i božanska narav nalaze u perihoretičkom jedinstvu. Vjernici sudjeluju u stvarnosti Svetog Trojstva.

Bog Duh značajno doprinosi pobožavanju vjernika. Sveti Duh izvršava regeneraciju i obnovu vjernika. Kada se vjernici nanovo rode od Svetog Duha, postaju novi stvorovi s novom naravi. Kada su ispunjeni Duhom, ispunjeni su samim Bogom. Dok se nastavljaju puniti Duhom kroz duhovne discipline, on je taj koji preobražava vjernike na Kristovu sliku. Božanski duh stvara Božji karakter u Isusovim učenicima.

Pobožavanje je također vrsta razmijenjenog života. Palo postojanje zamijenjeno je Kristovim božanskim životom. Krist je postao grijehom da bismo mi mogli postati pravednošću; Krist je postao siromašan, da bismo se mi obogatili. Krist je dao svoj život za nas na križu, daje nam svoj život dok vjerujemo u njega i živi svoj život kroz nas dok mu se predajemo. Dakle, više ne živi vjernik, nego Krist živi u njemu i kroz njega, kao što izjavljuje Pavao. Budući da je Kristov život božanski život, taj život pobožava primatelja.

Pobožavanje obuhvaća čitavo ljudsko biće: duh, dušu i tijelo. Ljudski duh je oživljen i ispunjen Božjim Duhom. Time postaje stalnim dotokom Božjeg života, koji prožima dušu i tijelo. Dok duša prima Božji život od duha, počinje razmišljati poput Boga. Emocije slijede božanske misli te osoba počinje donositi odluke koje su u skladu s Božjom voljom. Duša je iscijeljena i sazrijeva kroz taj cjeloživotni proces obnove. Tijelo je također iscijeljeno jer je prožimano Božjim životom, ali s vremenom umire. Tijelo će u konačnici biti uskrsnuto i proslavljeno pri Kristovu drugom dolasku.

Pobožavanje otkriva telos ljudskog postojanja, pa čak i čitavog stvorenja. Ko-

16 Općenito govoreći, čini se da učenje o tome kako brinuti za Zemlju ozbiljno nedostaje u evanđeoskim crkvama. 
načni je cilj ljudskog spasenja biti suobličen Kristovoj slici. Konačni je cilj stvorenja vratiti se u svoje stanje slave prije Pada. Stvorenje čeka na proslavljenu Božju djecu, tako da može i samo iskusiti obnovu i slavu. Proslavljeni ljudi su čimbenici u obnovi stvorenja. Konačni cilj, telos i skopos, jest da „Bog bude sve u svemu“ (1 Kor 15,28).

\section{Dobrobiti oblikovane doktrine pobožavanja}

Jedna od jakosti doktrine pobožavanja je naglasak na novom stvorenju umjesto na palom stvorenju. Takav fokus može biti snažna motivacija za kršćane da žive svojim novim životom. Pobožavanje obuhvaća plemeniti cilj: preobrazba na Kristovu sliku da bi se potaknula obnova čovječanstva i stvorenja. Doktrina pobožavanja pomaže nam da se odmaknemo od verzije „evanđelja“, gdje je kršćanin jedan entitet (grešnik), ali se mora ponašati kao drugi entitet (svetac). Takvo gledište prenosi nemoguću i oksimoronsku paradigmu za življenje: „Bog je svet, ti si grešnik, ali moraš se ponašati sveto i Bog će ti suditi za to“. Mislim da su mnogi kršćani oštećeni i obeshrabreni takvim porukama. Doktrina pobožavanja pomaže nam da se odmaknemo od takve vrste legalizma jer je iznimno odnosna. Ne radi se o poslušnosti pravilima, nego o odnosu s Bogom, drugim ljudima i stvorenjem. Obnova Božje slike u nama odvija se dok smo u interakciji s Bogom, drugim kršćanima u Crkvi i svijetom.

Doktrina pobožavanja također pruža vrijednu platformu i mogućnost za jedinstvo s drugim kršćanima. Njezina učenja ključna su za priču o Bogu i čovječanstvu kako je iznesena u Bibliji, a većina kršćana može se složiti s tim. Međutim, doktrina je toliko nepoznata i nepoučavana u evanđeoskim crkvama da njezino promicanje zahtijeva puno vremena i truda. S obzirom na to da je biblijska, povijesna i evanđeoska, doktrina pobožavanja mogla bi se podignuti iz marginalnosti $\mathrm{u}$ središte nauke evanđeoskih crkava, koje bi je mogle koristiti za vlastito probuđenje i dosezanje izgubljenih. Kao što Gorman kaže: „Ono što čovječanstvo treba je sadašnji pobožni i bogoliki život slobodan od Grijeha, i budući vječni život slobodan od Smrti. Drugim riječima, čovječanstvo treba sudjelovati u božanskom moralnom karakteru i u božanskom vječnom karakteru. To znači da su ljudi u potrebi za pravednošću i besmrtnošću, glavnim Božjim karakteristikama vezanim uz pobožavanje“ (Gorman 2015, Kindle lokacija 7088).

Razmišljati u okvirima pobožavanja može biti velika promjena paradigme za mnoge kršćane. Promjena će, nadamo se, biti pozitivna i ohrabrujuća jer ističe sudjelovanje u Božjem životu i naravi. Za koje bismo se veće dobro mogli boriti nego za naše pobožavanje i za pobožavanje Crkve, palog svijeta i čitavog stvorenja? Pavlova perspektiva pruža nam velike mogućnosti. „Obucite novog čovjeka, 
po Bogu stvorena u pravednosti i svetosti istine“ (Ef 4,24), „Jer umrijeste, i vaš je život skriven s Kristom u Bogu. Kad se pojavi Krist, život vaš, tada ćete se i vi $s$ njime pojaviti u slavi“ (Kol 3,3).

\section{Literatura}

Blackwell, Ben C. 2016. Christosis: Engaging Paul's Soteriology with His Patristic Interpreters. Grand Rapids: Eerdmans.

Corbin-Reuschling, Wyndy. 2014. "The Means and End in 2 Peter 1:3-11: The Theological and Moral Significance of Theōsis." Journal of Theological Interpretation 8, no. 2 (September): 275-286. Pristupljeno 26. svibnja 2017. ATLA Religion Database with ATLASerials, EBSCOhost.

Enns, Pete. 2010. “Genesis, Creation, and Ancient Interpreters: Adam and Eve's Nakedness." BioLogos. Pristupljeno 18. rujna 2017. http://biologos.org/ blogs/archive/genesis-creation-and-ancient-interpreters-adam-and-evesnakedness.

Gorman, Michael J. 2009. Inhabiting the Cruciform God: Kenosis, Justification, and Theosis in Paul's Narrative Soteriology. Grand Rapids: Eerdmans. Kindle.

Gorman, Michael J. 2011. "Romans: The First Christian Treatise on Theosis." Journal of Theological Interpretation 5, no. 1: 13-34. Pristupljeno 21. rujna 2017. ATLA Religion Database with ATLASerials, EBSCOhost.

Gorman, Michael J. 2015. Becoming the Gospel: Paul, Participation, and Mission. Grand Rapids: Eerdmans. Kindle.

HELPS Word-studies, 2011. Helps Ministries. Pristupljeno 14. rujna 2017. http://biblehub.com.

Litwa, David M. 2008. "2 Corinthians 3:18 and Its Implications for Theosis." Journal of Theological Interpretation 2, no. 1: 117-133. Pristupljeno 19. rujna 2017. ATLA Religion Database with ATLASerials, EBSCOhost.

Litwa, David M. 2012. We Are Being Transformed: Deification in Paul's Soteriology. Berlin: De Gruyter.

Maximus, Saint. 2015. The Writings of Saint Maximus the Confessor. Philadelphia: R.P. Pryne. Kindle.

McKim, Donald K. 1996. Westminster Dictionary of Theological Terms. Louisville: Westminster John Knox Press.

Olson, Roger E. 2007. "Deification in Contemporary Theology." Theology Today 64, no. 2 (July 1): 186-200. 
Oxford Dictionary, 2017. Oxford University Press. Pristupljeno 19. rujna 2017. https://en.oxforddictionaries.com.

Roberts, J. W. 1963. "Some Observations on the Meaning of 'Eternal Life' in the Gospel of John." Restoration Quarterly 7, no. 4: 186-193. Pristupljeno 20. rujna 2017. ATLA Religion Database with ATLASerials, EBSCOhost.

Russell, Norman. 2004. The Doctrine of Deification in the Greek Patristic Tradition. Oxford: Oxford University Press. Kindle.

Stott, John R. "In Christ': The Meaning and Implications of the Gospel of Jesus Christ." C. S. Lewis Institute. Springfield, VA. Pristupljeno 25. rujna 2017. http://www.cslewisinstitute.org/In_Christ_page1.

Vincent, Alan. 2008. The Good Fight of Faith. Shippensburg: Destiny Image Publishers.

Vishnevskaya, Elena. 2008. "Divinization as Perichoretic Embrace in Maximus the Confessor." In Partakers of the Divine Nature, 132-145. Grand Rapids: Baker Academic.

Wallace, Daniel B. 2000. The Basics of New Testament Syntax. Grand Rapids: Zondervan.

\author{
Goran Medved
}

\title{
Theosis (Deification) as a New Testament and Evangelical Doctrine
}

\begin{abstract}
Summary
This is the second one of the two articles by this author, which examine the doctrine of theosis, sometimes also called deification or divinization. The first article presented theosis as a biblical and historical doctrine. This article presents theosis as a New Testament and evangelical doctrine. The first part of this article deals with theosis in New Testament theology. The second part of this article gives a proposal for articulating an evangelical doctrine of theosis. Because of its New Testament support, theosis should occupy a much more prominent place in evangelical theology.
\end{abstract}

